\title{
Characterization of Phage-Resistant Strains Derived from Pseudomonas tolaasii 6264, which Causes Brown Blotch Disease
}

\author{
Yeong-Bae Yun, Ji-Hye Han, and Young-Kee Kim* \\ Department of Environmental and Biological Chemistry, Chungbuk National University, Cheongju 28644, Republic of Korea
}

\author{
Received: September 14, 2018 \\ Revised: September 28, 2018 \\ Accepted: October 1, 2018 \\ First published online \\ October 3, 2018 \\ *Corresponding author \\ Phone: +82-43-261-2560; \\ Fax: +82-43-271-5921; \\ E-mail: ykkim10@cbnu.ac.kr \\ pISSN 1017-7825, eISSN 1738-8872 \\ Copyright(C) 2018 by \\ The Korean Society for Microbiology \\ and Biotechnology
}

Pseudomonas tolaasii 6264 is a representative strain that causes bacterial blotch disease on the cultivated oyster mushroom, Pleurotus ostreatus. Bacteriophages are able to sterilize the pathogenic $P$. tolaasii strains, and therefore, they can be applied in creating disease-free mushroom cultivation farms, through a method known as "phage therapy". For successful phage therapy, the characterization of phage-resistant strains is necessary, since they are frequently induced from the original pathogenic bacteria in the presence of phages. When 10 different phages were incubated with $P$. tolaasii 6264, their corresponding phage-resistant strains were obtained. In this study, changes in pathogenic, genetic, and biochemical characteristics as well as the acquired phage resistance of these strains were investigated. In the phylogenetic analyses, all phage-resistant strains were identical to the original parent strain based on the sequence comparison of $16 \mathrm{~S}$ rRNA genes. When various phage-resistant strains were examined by three different methods, pitting test, white line test, and hemolytic activity, they were divided into three groups: strains showing all positive results in three tests, two positive in the first two tests, and all negative. Nevertheless, all phage-resistant strains showed that their pathogenic activities were reduced or completely lost.

Keywords: Bacteriophage, mushroom disease, pathogenicity, peptide toxin, phage therapy, tolaasin

\section{Introduction}

Pseudomonas tolaasii is a major bacterial strain that causes brown blotch disease on cultivated mushrooms [1]. The disease occurs on various mushrooms, such as Pleurotus ostreatus, Agaricus bisporus, and Flammulina velutipes. Tolaas first reported that brown blotch disease is a bacterial disease [2]. It is one of the major diseases in the mushroom cultivation industry and discourages farmers with serious economic losses. Since mushrooms are fresh food, antibiotics are not allowed to be used. In order to prevent the disease, bottling cultivation, sterilization of agricultural groundwater, fumigation of cultivation facilities, and plastic film mulching have been used. There has been some improvement, but no method has been completely successful in preventing the disease.

Bacteriophages are bacterial viruses that have attracted attention as an alternative to antibiotics as antibacterial agents [3, 4]. To prevent the appearance of antibioticresistant bacteria, the development of improved methods using new antimicrobial agents, bacteriophages, antibacterial peptides, and nanoparticles is necessary. Recently, research using bacteriophages has been actively carried out on livestock, agricultural, and marine products, to sterilize antibiotic-resistant bacteria [5-7]. However, the commercialization of phage therapy has been delayed due to difficulties in clinical application and the occurrence of phage-resistant pathogenic bacterial strains [8]. The induction of phage-resistant mutant (PRM) strains is overcome by the treatment of multiple phages, known as a phage cocktail [9]. Therefore, the understanding and prevention of PRM strains are essential for successful phage therapy.

Various phages against $P$. tolaasii were isolated and their bactericidal activities were measured. Phage therapy was apparently successful since no pathogens were observed in the presence of the specific phages [10]. However, PRM 
strains were induced after further incubation and they survived in the presence of the corresponding phages [11]. In this study, a number of PRM strains have been derived from one parent pathogen, $P$. tolaasii 6264 , and their genetic characteristics, biochemical activities, and pathogenicity were compared with those of the parent strain.

\section{Materials and Methods}

\section{Induction of PRM Strains}

P. tolaasii 6264 strain was inoculated in a Pseudomonas agar $\mathrm{F}$ (PAF, Difco, Lawrence, KS, USA; bacto-peptone $10 \mathrm{~g}$, bactotryptone $10 \mathrm{~g}$, glycerol $10 \mathrm{ml}, \mathrm{MgSO}_{4} 1.5 \mathrm{~g}, \mathrm{~K}_{2} \mathrm{HPO}_{4} 1.5 \mathrm{~g}$, and agar $15 \mathrm{~g} / \mathrm{l})$ semisolid medium made with $50 \%$ agar, poured onto a solid medium and hardened for $1 \mathrm{~h}$. Four microliters of a phage solution were added to the medium and cultured at $25^{\circ} \mathrm{C}$ for $48-$ $72 \mathrm{~h}$. Colonies of PRM strains appeared in the inside of phageplaques. A single colony that occurred inside a plaque was isolated and plated on solid medium. The isolated PRM strains were re-inoculated with the phage solution to confirm their growth in the presence of phage. They were suspended in $1 \mathrm{ml}$ storage medium containing $20 \%$ glycerol and stored at $-80^{\circ} \mathrm{C}$. PRM strains were induced by inoculation of various phages to the parent strain, P. tolaasii 6264, and those strains were called " $\mathrm{R}$ " and added to the number of phages used.

\section{Analysis of Genetic Characteristics}

The genetic characteristics of the PRM strains were investigated by comparing their 16S rRNA gene to that of the parent strain. Sequencing was performed using a $\operatorname{BigDye}(\mathrm{R})$ Terminator v3.1 Cycle Sequencing Kit from Applied Biosystems Co., Ltd. (Foster City, CA, USA). Polymerase chain reaction (PCR) was performed with the method presented by Khan and Jett [12]. After completion of the reaction, unreacted dNTPs and reagents were removed with ethanol and the results were obtained using an ABI 3730xl DNA Analyzer. The results were compared with each sequence of ribosomal DNA in the GenBank database using the BLASTN program and the homology and identification of sequences were analyzed by the ezTaxon server (http:// www.ezbiocloud.net/eztaxon) [13], Clustal W, and Mega 7.0 program [14].

\section{Biochemical Activities of Parent Strain and PRM Strains}

The API 20NE kit (Biomérieux, Paris, France) was used to investigate the biochemical characteristics of the parent strain and PRM strains. Measurement was carried out according to the manufacturer's instructions. Briefly, the colony of each strain was inoculated into sterile physiological saline $(0.85 \%$ sodium chloride solution) and the solution was filled into various metabolic activity wells and they were incubated at $30^{\circ} \mathrm{C}$ for $24-48 \mathrm{~h}$.

\section{Pitting Test and White Line Test}

A pitting test was carried out using the fruiting body of a button mushroom (Agaricus bisporus) according to the method presented by Gandy [15]. The fruiting body of the mushroom was cut horizontally and the culture medium $\left(10^{8}-10^{9} \mathrm{CFU} / \mathrm{ml}\right)$ or supernatants were dropped onto the surface of the fruiting body. After incubation at $25^{\circ} \mathrm{C}$ for $12-24 \mathrm{~h}$, discoloration and sunken areas on the surface were observed.

After Pseudomonas reactans ATCC 51314, a white-line forming strain, was inoculated in the PAF solid medium in a straight line, $1 \mu \mathrm{l}$ culture medium of the PRM strain was inoculated at a distance of $5 \mathrm{~mm}$. The inoculated plates were incubated at $25^{\circ} \mathrm{C}$ for $24-48 \mathrm{~h}$ to determine the appearance of white sedimentation between the two strains.

\section{Measurement of Hemolytic Activity}

The hemolytic activity of tolaasin or its analogues was measured using red blood cells (erythrocytes) according to the method presented by Rainey et al. [16]. Erythrocytes were collected from the vena cava (major vein) of rat and stored at $4^{\circ} \mathrm{C}$. This was diluted 10 times with HEPES-buffered saline at the time of use. Tolaasin at $1 \mathrm{HU}$, which makes hemolysis $1 \%$ erythrocytes within $30 \mathrm{~min}$, was used for the measurement of hemolytic activity by monitoring absorbance at $600 \mathrm{~nm}$ using a UV/vis spectrophotometer (U-2000, Hitachi, Japan).

\section{Opacity of Colonies}

PRM strains were inoculated in the PAF solid medium. After $24 \mathrm{~h}$ incubation, the turbidity of the colonies of each strain was observed. In order to determine the opacity of the colonies, the plates were put on grid paper in a lightbox. Colonies of each strain were divided into opaque $(\mathrm{O})$, translucent $(\mathrm{TL})$, and transparent (TP) according to transparency.

\section{Results}

\section{Isolation and Cross-Reactivity of PRM Strains}

Thirteen PRM strains were isolated in the middle of large plaques formed by 10 different bacteriophages against a parent bacterium, P. tolaasii 6264 (Table 1). The PRM strains $21 \mathrm{R}, 32 \mathrm{R}, 42 \mathrm{R}, 44 \mathrm{R}$, and $83 \mathrm{R}$ were isolated from the highly toxic phages $\phi 6 \mathrm{~b} 21, \phi 6 \mathrm{~b} 32, \phi 6 \mathrm{~b} 42, \phi 6 \mathrm{~b} 44$, and $\phi 6 \mathrm{~h} 83$, respectively. The PRM strains $31 \mathrm{R}(\mathrm{a}, \mathrm{b}), 5 \mathrm{R}, 7 \mathrm{R}, 82 \mathrm{R}(\mathrm{a}, \mathrm{b}, \mathrm{c})$ were isolated from medium toxic phages $\phi 6 \mathrm{~b} 31, \phi 6 \mathrm{~g} 5, \phi 6 \mathrm{~b} 7$, and $\phi 6 h 82$, respectively. The PRM $1 \mathrm{R}$ strain was induced by a low toxic phage, $\phi 6 \mathrm{~b} 1$. The PRM strains were induced as single or multiple colonies inside the plaque (Fig. 1). In the cases of phages $\phi 6 \mathrm{~b} 31$ and $\phi 6 \mathrm{~h} 82$, two and three strains of PRM were found in one plaque, respectively.

In order to investigate the susceptibility of PRM strains to different phages, each PRM strain was treated with 10 phages. The phages with the same host range could be classified into the same phage type. Ten phages were 
Table 1. List of PRM strains and corresponding phages.

\begin{tabular}{ccc}
\hline Parent strain & Bacteriophage & Induced *PRM strain \\
\hline & $\phi 6 \mathrm{~b} 1$ & $1 \mathrm{R}$ \\
& $\phi 6 \mathrm{~b} 21$ & $21 \mathrm{R}$ \\
& $\phi 6 \mathrm{~b} 31$ & $31 \mathrm{aR}$ \\
& $\phi 6 \mathrm{~b} 32$ & $31 \mathrm{bR}$ \\
Pseudomonas tolaasii & $\phi 6 \mathrm{~b} 42$ & $32 \mathrm{R}$ \\
6264 & $\phi 6 \mathrm{~b} 44$ & $42 \mathrm{R}$ \\
& $\phi 6 \mathrm{~g} 5$ & $44 \mathrm{R}$ \\
& $\phi 6 \mathrm{~b} 7$ & $5 \mathrm{R}$ \\
& & $7 \mathrm{R}$ \\
& $\phi 6 \mathrm{~h} 82$ & $82 \mathrm{aR}$ \\
& & $82 \mathrm{bR}$ \\
& & $86 \mathrm{~h} 83$ \\
\end{tabular}

*PRM: phage-resistant mutant.

divided into six types according to the broadness of the host range for those PRM strains (Table 2). Phage $\phi 695$, called type 2, with the narrowest host range, is able to infect only three of eight PRM strains. Meanwhile, phage $\phi 6$ h83, called type 6, can infect all types of seven PRM bacterial groups except 83R strain, its self-induced PRM strain. Phages $\phi 6 \mathrm{~b} 31, \phi 6 \mathrm{~b} 42$, and $\phi 6 \mathrm{~b} 7$ were classified into type 3. Phages $\phi 6 \mathrm{~b} 32, \phi 6 \mathrm{~b} 44$, and $\phi 6 \mathrm{~h} 82$, which have the

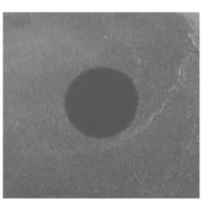

Control

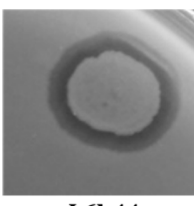

ф6b44

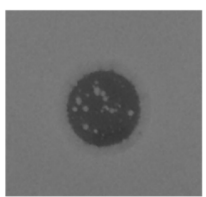

$\phi 6 b 21$

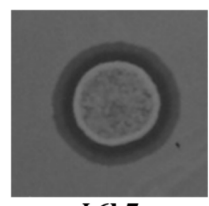

$\phi 6 \mathbf{b} 7$

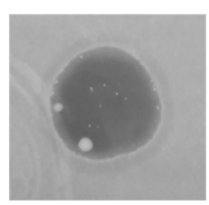

$\Phi 6 b 31$

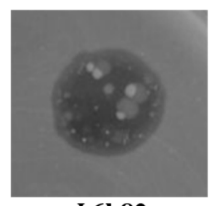

$\Phi 6 h 82$

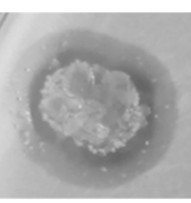

$\phi 6 b 42$

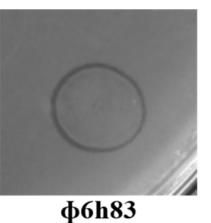

Fig. 1. Colony formations of phage-resistant bacteria (PRM) inside plaques.

same reactivity to PRM strains, belong to type 4 . Phages $\phi 6 \mathrm{~b} 1$ and $\phi 6 \mathrm{~b} 21$ belong to type 1 and type 5, respectively. All PRM strains derived from type 3 phage showed the same susceptibility to phages. However, those of PRM strains derived from type 4 phage were divided into three groups with different susceptibility to type 1 and type 5 phages.

\section{Genetic and Biochemical Characters of PRM Strains}

In the phylogenetic analyses of $16 \mathrm{~S}$ rRNA gene sequences of the PRM strains, the nucleotide sequences of the PRM strains $1 \mathrm{R}, 21 \mathrm{R}, 31 \mathrm{aR}, 44 \mathrm{R}, 5 \mathrm{R}, 82 \mathrm{aR}, 82 \mathrm{bR}$, and $82 \mathrm{cR}$ were identical to that of the parent strain; however, those of the $31 \mathrm{bR}, 32 \mathrm{R}, 42 \mathrm{R}, 7 \mathrm{R}$, and $83 \mathrm{R}$ strains were slightly different

Table 2. Cross-susceptibility of PRM strains to various bacteriophages.

\begin{tabular}{|c|c|c|c|c|c|c|}
\hline Phage & Type 1 & Type 2 & Type 3 & Type 4 & Type 5 & Type 6 \\
\hline PRM strain & $\phi 6 \mathrm{~b} 1$ & $\phi 6 \mathrm{~g} 5$ & $\begin{array}{c}\phi 6 \mathrm{~b} 31 \\
\phi 6 \mathrm{~b} 42 \\
\phi 6 \mathrm{~b} 7\end{array}$ & $\begin{array}{l}\phi 6 \mathrm{~b} 32 \\
\phi 6 \mathrm{~b} 44 \\
\phi 6 \mathrm{~h} 82\end{array}$ & $\phi 6 \mathrm{~b} 21$ & $\phi 6 h 83$ \\
\hline $6264^{*}$ & ${ }^{\mathrm{a}} \mathrm{O}$ & $\mathrm{O}$ & $\mathrm{O}$ & $\mathrm{O}$ & $\mathrm{O}$ & $\mathrm{O}$ \\
\hline $1 R$ & $\mathrm{c} \times$ & $\mathrm{O}$ & $\mathrm{O}$ & $\mathrm{O}$ & $\mathrm{O}$ & $\mathrm{O}$ \\
\hline $5 R$ & $\mathrm{O}$ & (x) & $\mathrm{O}$ & $\mathrm{O}$ & $\mathrm{O}$ & $\mathrm{O}$ \\
\hline $\begin{array}{l}31 \mathrm{aR}, 42 \mathrm{R} \\
31 \mathrm{bR}, 7 \mathrm{R}\end{array}$ & $\mathrm{O}$ & $\mathrm{O}$ & (x) & $\mathrm{O}$ & $\mathrm{O}$ & $\mathrm{O}$ \\
\hline $21 R$ & ${ }^{b} X$ & $\mathrm{O}$ & $\mathrm{O}$ & $\mathrm{O}$ & (x) & $\mathrm{O}$ \\
\hline $44 \mathrm{R}, 82 \mathrm{cR}$ & $\mathrm{O}$ & $x$ & $\mathrm{O}$ & (x) & $\mathrm{O}$ & $\mathrm{O}$ \\
\hline $82 \mathrm{aR}$ & $X$ & $x$ & $\mathrm{O}$ & (x) & $\mathrm{O}$ & $\mathrm{O}$ \\
\hline $32 \mathrm{R}, 82 \mathrm{bR}$ & $\mathrm{O}$ & $x$ & $\mathrm{O}$ & (x) & $x$ & $\mathrm{O}$ \\
\hline $83 R$ & $x$ & $x$ & $x$ & $x$ & $\mathrm{O}$ & (x) \\
\hline
\end{tabular}

*Parent strain.

${ }^{a} \mathrm{O}$, Susceptible to phage.

${ }^{\mathrm{b}} \mathrm{X}$, Resistant to phage.

$\mathrm{c}(\mathrm{X})$, Phage responsible for the induction of the corresponding PRM strain. 


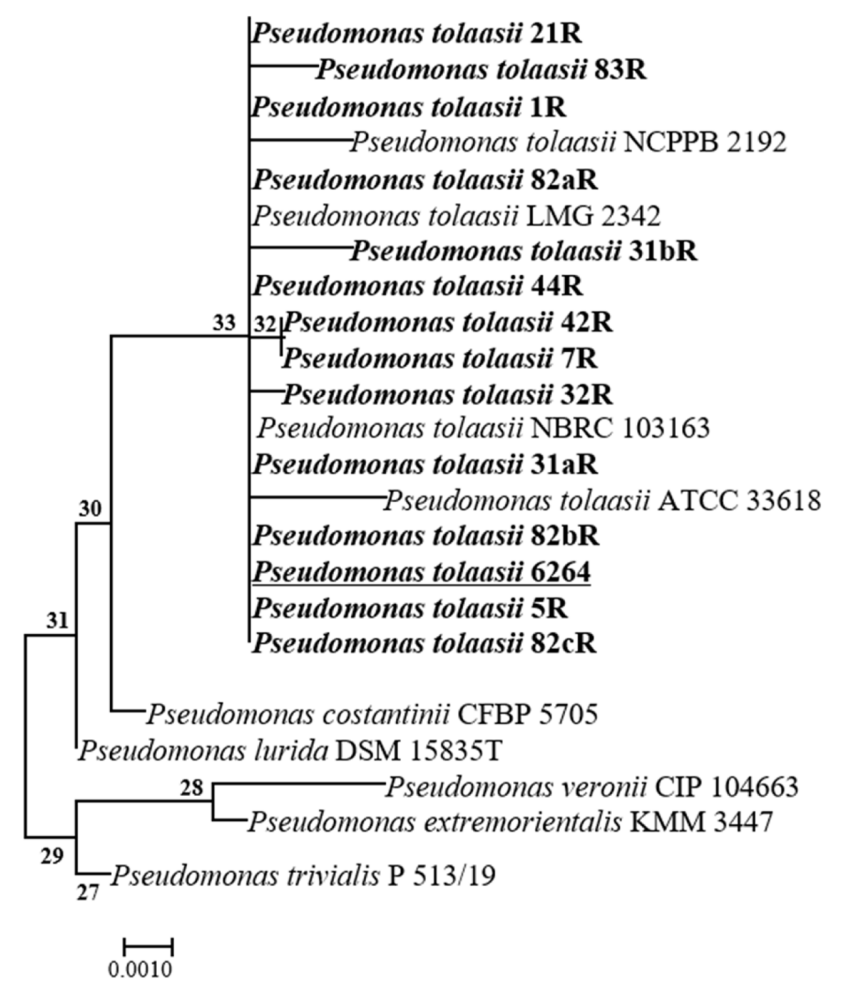

Fig. 2. Phylogenetic tree of the PRM strains. The parent strain, P. tolaasii 6264, is underlined.

from that of the parent strain (Fig. 2). Furthermore, these PRM strains showed high homology over 99.5\% with P. tolaasii ATCC 33618. This is higher than the species differentiation threshold of $98.6 \%$, indicating that all PRM strains originated from the parent strain, P. tolaasii 6264 .

In order to evaluate any changes in biochemical

Table 3. Metabolic activities of the parent and PRM strains.

\begin{tabular}{|c|c|c|c|}
\hline \multicolumn{2}{|c|}{ PRM strain } & ADH & GEL \\
\hline \multicolumn{2}{|c|}{$6264^{*}$} & + & + \\
\hline $1 \mathrm{R}$ & $21 R$ & & \\
\hline $31 \mathrm{aR}$ & $31 \mathrm{bR}$ & & \\
\hline $32 \mathrm{R}$ & $42 \mathrm{R}$ & $a_{-}-(+)$ & + \\
\hline $44 \mathrm{R}$ & $5 R$ & & $T$ \\
\hline $7 \mathrm{R}$ & $82 \mathrm{bR}$ & & \\
\hline \multicolumn{2}{|c|}{$82 c R$} & & \\
\hline 82aR & $83 \mathrm{R}$ & $-(+)$ & - \\
\hline
\end{tabular}

The API Kit (20NE) was used to measure the metabolic activities of PRM strains. The same results were obtained for all strains: $\mathrm{NO}_{3}(-), \mathrm{TRP}(-), \mathrm{GLU}($ ferment. -), $\operatorname{URE}(-), \operatorname{ESC}(-), \operatorname{PNPG}(-), \operatorname{ARA}(-), \operatorname{MAL}(-), \operatorname{ADI}(-), \operatorname{PAC}(-), \operatorname{GLU}(+), \operatorname{MNE}(+)$, $\mathrm{NAM}(+), \mathrm{NAG}(+), \mathrm{GNT}(+), \mathrm{CAP}(+), \operatorname{MLT}(+), \mathrm{CIT}(+), \mathrm{OX}(+)$.

*Parent strain.

${ }^{\mathrm{a}}-(+), 24 \mathrm{~h}$ incubation: -, $48 \mathrm{~h}$ incubation: +

+ , positive reaction; -, negative reaction.
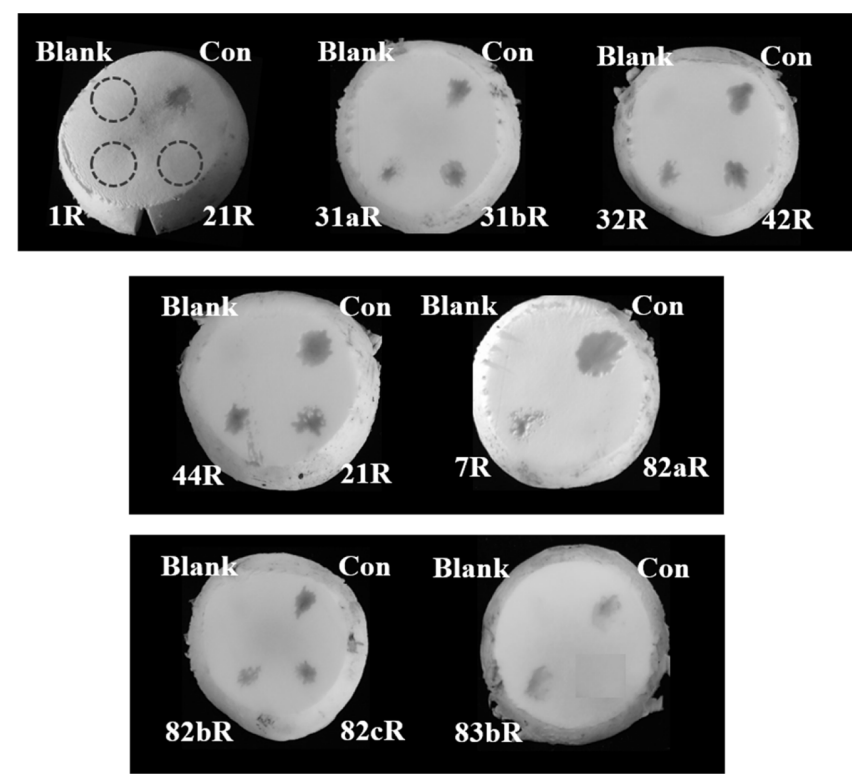

Fig. 3. Brown blotch formations by the parent strain and PRM strains. Con, blotches formed by the parent strain.

characteristics between the parent strain and the corresponding PRM strains, 21 metabolic activities were measured. Differences were observed in the activities of $\mathrm{ADH}$ (arginine dihydrolase) and GEL (gelatin hydrolysis). The other 19 metabolic activities were consistent with all bacterial strains (Table 3). The activity of ADH was dependent on the incubation time and was not observed in all PRM strains within $24 \mathrm{~h}$ incubation; however, it became positive after $48 \mathrm{~h}$. The only difference was observed in GEL activity, and the PRM strains $82 \mathrm{aR}$ and $83 \mathrm{R}$ showed negative in GEL activity. Therefore, when the PRM strains were induced, most of the metabolic activities except for the $\mathrm{ADH}$ and GEL activities were not changed.

\section{Pathogenicity of PRM Strains}

To compare the pathogenicity of the PRM strains to that of the parent strain, their cytotoxicities were measured by using both pitting test and hemolytic activity. In the pitting test, the strength of the pathogenicity was measured by the size of blotch formed and the degree of sinking of the blotch surface. At $24 \mathrm{~h}$ incubation after the addition of one drop of culture supernatant, brown blotches were formed, and the tissue was submerged at the inoculation site (Fig. 3). When the area of the blotches and the degree of sinking were compared, the strains $31 \mathrm{aR}, 32 \mathrm{R}, 7 \mathrm{R}, 82 \mathrm{bR}$, and $82 \mathrm{cR}$ were less toxic since their culture extracts made smaller blotches than that of the parent strain. PRM strains 31bR, 42R, 44R, 5R, and 83R made blotches with similar 


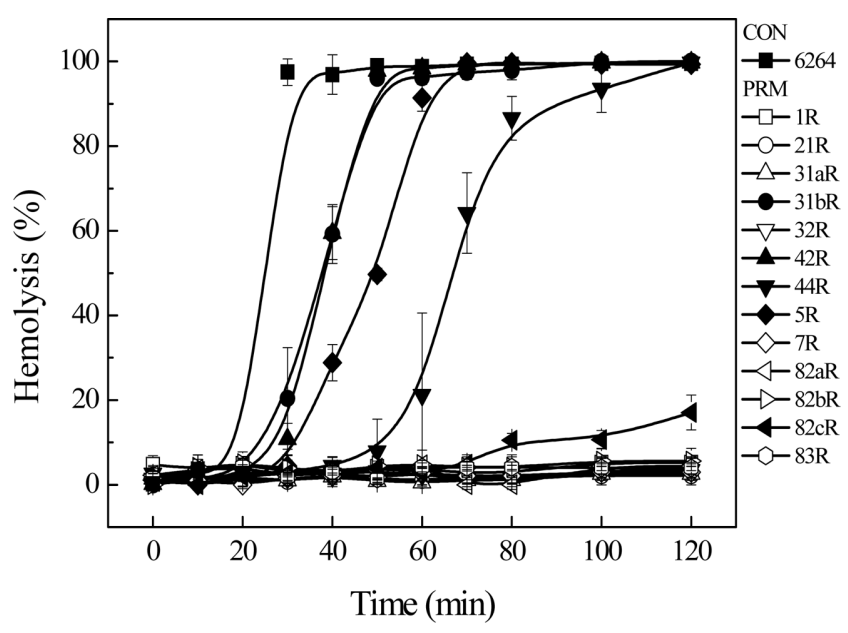

Fig. 4. Hemolytic activities of the PRM strains.

sizes, but not bigger than that of the parent strain. However, PRM strains, 1R, 21R, and $82 \mathrm{aR}$, did not form blotches. Therefore, the PRM strains can cause disease, but none of them have stronger pathogenicity than the parent strain.

The tolaasin peptides secreted by $P$. tolaasii are poreforming toxins and are toxic to the erythrocyte membrane as well as the mushroom cell membrane. Hemolytic activity was measured and evaluated as cytotoxic activity. When hemolysis was measured after the addition of culture supernatant, a time-dependent hemolytic curve was shown in Fig. 4. The hemolytic activity of each strain was evaluated as $\mathrm{T}_{50}$, the time required for $50 \%$ hemolysis. The parent strain had a rapid hemolysis rate and its $T_{50}$ was $25.0 \mathrm{~min}$, while the $\mathrm{T}_{50}$ of the PRM strains, $31 \mathrm{bR}$ and $42 \mathrm{R}$, was about $38 \mathrm{~min}$. The $T_{50}$ values of the $5 R$ and $44 R$ strains were 49.1 and $66.8 \mathrm{~min}$, respectively, and they showed weak cytotoxicity. The $82 \mathrm{cR}$ strain showed very poor hemolytic activity and it mediated only $20 \%$ hemolysis for $2 \mathrm{~h}$. The rest of the PRM strains did not show any cytotoxic activity to erythrocytes (Fig. 4).

In order to identify the cause of changes in pathogenicity, toxin secretion and the morphological characteristics of these PRM strains were investigated. The tolaasin secreted by Pseudomonas tolaasii is known to bind to the "white line inducing principle" (WLIP) toxin secreted by Pseudomonas reactans and forms white line precipitation [17]. According to the result of the white line test, the parent strain was positive as it formed a white line, or peptide precipitation, confirming it as a tolaasin-secreting strain. In the analyses of the PRM strains, the strains 31aR, 31bR, 32R, 42R, 44R, $5 \mathrm{R}, 7 \mathrm{R}, 82 \mathrm{bR}, 82 \mathrm{cR}$, and $83 \mathrm{R}$ also formed white precipitates,
Table 4. Comparison of various phenotypes of PRM strains.

\begin{tabular}{lcccc}
\hline $\begin{array}{c}\text { PRM } \\
\text { strain }\end{array}$ & $\begin{array}{c}\text { a Pitting } \\
\text { test }\end{array}$ & $\begin{array}{c}{ }^{\mathrm{b}} \text { White } \\
\text { line test }\end{array}$ & $\begin{array}{c}{ }^{\mathrm{c}} \text { Hemolytic } \\
\text { activity }\end{array}$ & $\begin{array}{c}{ }^{\mathrm{d}} \text { Opacity } \\
\text { of colony }\end{array}$ \\
\hline $6264^{*}$ & $\mathrm{P}$ & $\mathrm{P}$ & $\mathrm{H}$ & $\mathrm{O}$ \\
$1 \mathrm{R}$ & $\mathrm{N}$ & $\mathrm{N}$ & $\mathrm{N}$ & $\mathrm{TP}$ \\
$21 \mathrm{R}$ & $\mathrm{N}$ & $\mathrm{N}$ & $\mathrm{N}$ & $\mathrm{TP}$ \\
$31 \mathrm{aR}$ & $\mathrm{P}$ & $\mathrm{P}$ & $\mathrm{N}$ & $\mathrm{TL}$ \\
$31 \mathrm{bR}$ & $\mathrm{P}$ & $\mathrm{P}$ & $\mathrm{H}$ & $\mathrm{O}$ \\
$32 \mathrm{R}$ & $\mathrm{P}$ & $\mathrm{P}$ & $\mathrm{N}$ & $\mathrm{TL}$ \\
$42 \mathrm{R}$ & $\mathrm{P}$ & $\mathrm{P}$ & $\mathrm{H}$ & $\mathrm{O}$ \\
$44 \mathrm{R}$ & $\mathrm{P}$ & $\mathrm{P}$ & $\mathrm{L}$ & $\mathrm{O}$ \\
$5 \mathrm{R}$ & $\mathrm{P}$ & $\mathrm{P}$ & $\mathrm{H}$ & $\mathrm{O}$ \\
$7 \mathrm{R}$ & $\mathrm{P}$ & $\mathrm{P}$ & $\mathrm{N}$ & $\mathrm{TL}$ \\
$82 \mathrm{aR}$ & $\mathrm{N}$ & $\mathrm{N}$ & $\mathrm{N}$ & $\mathrm{TP}$ \\
$82 \mathrm{bR}$ & $\mathrm{P}$ & $\mathrm{P}$ & $\mathrm{N}$ & $\mathrm{TL}$ \\
$82 \mathrm{cR}$ & $\mathrm{P}$ & $\mathrm{P}$ & $\mathrm{N}$ & $\mathrm{O}$ \\
$83 \mathrm{R}$ & $\mathrm{P}$ & $\mathrm{P}$ & $\mathrm{N}$ & $\mathrm{TL}$ \\
\hline
\end{tabular}

*Parent strain.

${ }^{a, b} \mathrm{P}$, Positive reactions in brown blotch formation and white line formation; $\mathrm{N}$, Negative reaction.

${ }^{c} \mathrm{H}$, High activity; L, Low activity; N, No activity.

${ }^{\mathrm{d}} \mathrm{O}$, Opaque; TL, Translucent; TP, Transparent.

while the strains $1 R, 21 R$, and $82 a R$ did not form any white lines. In addition, the PRM strains derived from the parent strain showed some differences in colony turbidity. The PRM strains 31bR, 42R, 44R, 5R, and 82cR grew into an opaque colony, similar to that of the parent strain. However, the PRM strains $1 \mathrm{R}, 21 \mathrm{R}$, and $82 \mathrm{aR}$ made transparent colonies. The remaining PRM strains formed translucent colonies (Table 4). The PRM strains with opaque colonies all showed positive in three tests, pitting test, white line-forming ability, and hemolysis; however, those with transparent colonies showed all negative in three tests.

\section{Discussion}

For the control of brown blotch disease, bacteriophages were successful in sterilizing pathogenic $P$. tolaasii strains [10]. Despite the excellent bactericidal activity of the bacteriophages, the PRM strains were easily induced in the presence of phages. For successful phage therapy, the pathogenic and biochemical characteristics of the PRM strains were investigated [11]. PRM strains were derived from the parent strain, $P$. tolaasii 6264, in the presence of various virulent phages. When their characteristics were compared, no correlations between the pathogenic characters 
of the PRM strains and the phages were clearly found. Since the mechanisms for obtaining resistance against phages are variable $[18,19]$, the characteristics of the PRM strains may vary widely and it may be difficult to compare different mutant strains. Nevertheless, by revealing correlations between the parent strain and the PRM strains, it may provide deeper insight into the problems that occur with various PRM strains.

Ten different phages were classified into six types depending on their host ranges to 13 PRM strains. Although the PRM strains derived from a single parent strain and were induced by similar phages sharing single host bacteria exhibited various phage sensitivities (Table 2), these results suggest that the phage type may not determine the phage resistance characteristics of PRM strains. Bacterial host strains require some modifications of existing cellular structures and biosystems to obtain phage resistance. In this process, the bacterial phenotype can be changed in various ways [20,21]. The hemolytic activity of the PRM strains decreased by more than $80 \%$ at $30 \mathrm{~min}$, or completely disappeared (Fig. 4), and the blotch-forming ability of the PRM strains also decreased in degree of sunken area and discoloration (Fig. 3). These results are very similar to those of previous studies that showed the reduced pathogenicity of the PRM strains induced by Salmonella enterica [22]. León and Bastías [23] reported two possibilities that reduce the pathogenicity of the PRM strains: (1) Lipopolysaccharide (LPS) and outer membrane proteins (OMPs) of Gram-negative strains, bacterial phage receptors, are closely related to the bacterial pathogenicity. Therefore, structural alterations of LPS and OMPs may change the pathogenicity of the PRM strains. (2) Mutations of gene regulatory factors may be able to reduce their pathogenic activities.

Four different phenotypes of the parent and the PRM strains were compared (Table 4). The first three phenotypes are directly related to pathogenic activities and the fourth is the shape of the colony. PRM strains that formed transparent colonies showed a complete loss of pathogenicity by coming up negative in the first three tests; however, the PRM strains that grew opaque colonies were all positive. Interestingly, the PRM strains that formed translucent colonies exhibited only blotch-forming ability without hemolytic activity, similar to the pathogenic characteristics of the P1 $\beta$ subgroup strains of $P$. tolaasii [24]. The molecular mechanism behind the pathogenic variations of the PRM strains is not known, but it may vary depending on the composition of peptide toxins. The pattern of peptide toxins and their molecular weights secreted by the PRM strains should be examined and compared with the peptides secreted by the parent strain, P. tolaasii 6264 . Nutkins et al. [25] reported that strains with blotch-forming ability without hemolytic activity were caused by a change in the composition of tolaasin analogues. Furthermore, in studies on Pseudomonas syringae pv. lachrymans and Pseudomonas aeruginosa, strains with rough colonies were reported to have quantitative and qualitative differences in lipopolysaccharide production compared to strains with smooth colonies. Fett et al. [26] found that exopolysaccharide (EPS)-producing Pseudomonas spp. formed a non-lytic colony that was different from the mucous colonies of the parent strain. These results indicate that bacterial EPS production inhibits the adsorption of bacteriophages, changes colony shape, and influences the pathogenicity of bacteria [27].

This study was carried out to investigate the characteristics of PRM strains that may cause problems for the practical application of phage therapy in mushroom cultivation. The results shown in this study suggest that the induced PRM strains are converted into non- or less-pathogenic strains when they acquire phage resistance. Phage resistance mechanism of $P$. tolaasii is not known. It is possible that the virulence of PRM strains may strengthen again; however, reacquirement of pathogenicity was not observed in any of the PRM strains after several generations. When phages are spread widely in the cultivation area and sterilize pathogenic bacteria, blotch disease will be successfully suppressed. Furthermore, the phages are consistently present in mushroom cultivation beds with bactericidal activity. When the PRM strains are induced and become the dominant species, they will not threaten mushroom cultivation with reduced pathogenic activities. The PRM strains may compete and suppress the major pathogenic strains, and therefore may inhibit the occurrence and progression of brown blotch disease. Phage therapy can be performed continuously and successfully without interruption by PRM strains.

\section{Acknowledgments}

This research was supported by the Basic Science Research Program through the National Research Foundation of Korea (NRF) funded by the Ministry of Education (2017R1D1A3B03032718).

\section{Conflict of Interest}

The authors have no financial conflicts of interest to declare. 


\section{References}

1. Paine SG. 1919. Studies in bacteriosis. II. A brown blotch disease of cultivated mushrooms. Ann. Appl. Biol. 5: 206-219.

2. Tolaas AG. 1915. A bacterial disease of cultivated mushrooms. Phytopathol. 5: 51-54.

3. Housby JN, Mann NH. 2009. Phage therapy. Drug Discov. Today 14: 536-540.

4. Lu TK, Koeris MS. 2011. The next generation of bacteriophage therapy. Curr. Opin. Micorbiol. 14: 524-531.

5. Wright A, Hawkins CH, Änggård EE, Harper DR. 2009. A controlled clinical trial of a therapeutic bacteriophage preparation in chronic otitis due to antibiotic-resistant Pseudomonas aeruginosa; a preliminary report of efficacy. Clin. Otolaryngol. 34: 349-357.

6. Fujiwara A, Fujisawa M, Hamasaki R, Kawasaki T, Fujie M, Yamada T. 2011. Biocontrol of Ralstonia solanacearum by treatment with lytic bacteriophages. Appl. Environ. Microbiol. 77: 4155-4162.

7. Yosef I, Kiro R, Molshanski-Mor S, Edgar R, Qimron U. 2014. Different approaches for using bacteriophages against antibiotic-resistant bacteria. Bacteriophage 4: e28491.

8. Parracho HM, Burrowes BH, Enright MC, McConville ML, Harper DR. 2012. The role of regulated clinical trials in the development of bacteriophage therapeutics. Mol. Genet. Med. 6: 279-286.

9. Kelly D, McAuliffe O, Ross RP, O’Mahony J, Coffey A. 2011. Development of a broad-host-range phage cocktail for biocontrol. Bioeng. Bugs 2: 31-37.

10. Kim MH, Park SW, Kim YK. 2011. Bacteriophages of Pseudomonas tolaasii for the biological control of brown blotch disease. J. Korean Soc. Appl. Biol. Chem. 54: 99-104.

11. Park SJ, Han JH, Kim YK. 2016. Isolation of bacteriophageresistant Pseudomonas tolaasii strains and their pathogenic characters. J. Appl. Biol. Chem. 59: 351-356.

12. Khan A, Jett J. 2004. Cycle sequencing using bigdye v3.1: Performed on fosmid DNA template. http://www.jgi.doe.gov/ sequencing/protocols/BigDyev3.1FosmidCycleSequencingSOP. doc.

13. Kim OS, Cho YJ, Lee K, Yoon SH, Kim M, Na H, et al. 2012. Introducing EzTaxon-e: a prokaryotic 16s rRNA gene sequence database with phylotypes that represent uncultured species. Int. J. Syst. Evol. Microbiol. 62: 716-721.

14. Thompson JD, Higgins DG, Gibson TJ. 1994. CLUSTAL W: improving the sensitivity of progressive multiple sequence alignment through sequence weighting, position-specific gap penalties and weight matrix choice. Nucleic Acids Res. 22: 4673-4680.

15. Gandy DG. 1968. pp. 150-154. A Technique for Screening Bacteria Causing Brown Blotch of Cultivated Mushrooms. Annual Report Glasshouse Crops Research Institute 1967.

16. Rainey PB, Brodey CL, Johnstone K. 1991. Biological properties and spectrum of activity of tolaasin, a lipodepsipeptide toxin produced by the mushroom pathogen Pseudomonas tolaasii. Physiol. Mol. Plant. Pathol. 39: 57-70.

17. Lo Cantore P, Giorgio A, Iacobellis NS. 2015. Bioactivity of volatile organic compounds produced by Pseudomonas tolaasii. Front. Microbiol. 6: 1802.

18. Simon JL, Julie ES, Sylvain M. 2010. Bacteriophage resistance mechanisms. Nat. Rev. Microbiol. 8: 317-327.

19. Koskella B, Brockhurst MA. 2014. Bacteria-phage coevolution as a driver of ecological and evolutionary processes in microbial communities. FEMS Microbiol. Rev. 38: 916-931.

20. Brüssow H, Canchaya C, Hardt W, Bru H. 2004. Phages and the evolution of bacterial pathogens: from genomic rearrangements to lysogenic conversion. Microbiol. Mol. Biol. Rev. 68: 560-602.

21. Filippov AA, Sergueev KV, He Y, Huang XZ, Gnade BT, Mueller AJ, et al. 2011. Bacteriophage-resistant mutants in Yersinia pestis: identification of phage receptors and attenuation for mice. PLoS One 6: e25486.

22. Capparelli R, Nocerino N, Iannaccone M, Ercolini D, Parlato M, Chiara M, et al. 2010. Bacteriophage therapy of Salmonella enterica: a fresh appraisal of bacteriophage therapy. J. Infect. Dis. 201: 52-61.

23. León M, Bastías R. 2015. Virulence reduction in bacteriophage resistant bacteria. Front. Microbiol. 6: 343.

24. Yun YB, Park SW, Cha JS, Kim YK. 2013. Biological characterization of various strains of Pseudomonas tolaasii that causes brown blotch disease. J. Korean Soc. Appl. Biol. Chem. 56: 41-45.

25. Nutkins JC, Mortishire-Smith RJ, Williams DH, Packman LC, Brodey CL, Rainey PB, et al. 1991. Structure determination of tolaasin, an extracellular lipodepsipeptide produced by the mushroom pathogen Pseudomonas tolaasii paine. J. Am. Chem. Soc. 113: 2621-2627.

26. Fett WF, Wells JM, Cescutti P, Wijey C. 1995. Identification of exopolysaccharides produced by fluorescent Pseudomonads associated with commercial mushroom (Agaricus bisporus) production. Appl. Environ. Microbiol. 61: 513-517.

27. Labrie SJ, Samson JE, Moineau S. 2010. Bacteriophage resistance mechanisms. Nat. Rev. Microbiol. 8: 317-327. 